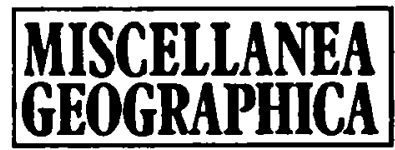

WARSZAWA 1996 Vol. 7

Jolanta Wawer

\title{
THE RATE OF HEATING AND COOLING OF THE AIR IN TOWN AND OUTSIDE OF IT
}

Changes in the structure of the heat balance and in the conditions of air flow within the overbuilt areas are the main causes of the increase of air temperature in town, that is - of the appearance of the urban heat island.

Although the heat island in Warsaw is a common phenomenon, but not necessarily an everyday one, and its development is not always alike. It depends upon the weather conditions which exist during the daily cycle, and which are differentiated over the year.

It is known that during the day we observe slower heating of the overbuilt areas, and then during the evening and night - its slower cooling, when it is compared to the surroundings, usually covered with vegetation.

That is why the greatest temperature differences between the town and its surroundings occur in the evening and during the night, while the smallest ones - at around noon (when temperature in town may even happen to be lower than outside of it). It is also known that the advantageous conditions for emergence of the urban heat island are provided by the high pressure weather type - warm, cloudless and windless.

The rate of change of air temperature within the urban built up areas is differentiated: heating in the morning hours $(\Delta T / \Delta t>0)$ and then cooling in the evening and night hours $(\Delta T / \Delta t<0)$.

The present report deals with an attempt at the identification of the magnitude of differentiation of the two measures, i.e. of the rates of heating and cooling. Particular attention was paid to these days, during which the urban heat island is characterized by high $\left(\Delta T>3^{\circ} \mathrm{C}\right)$ and very high $\left(\Delta T>5^{\circ} \mathrm{C}\right)$ intensity. It is namely known that during the days of the low pressure weather - cloudy and windy - thermal differences between town and its surroundings get far less distinct (Kossowska, 1973; Stopa-Boryczka et al., 1984, 1991; Wawer, 1992, 1994).

The basis for the study was constituted by the everyday hourly values of air temperature acquired from the thermograms of selected days from the period of 1961-1965 at the station of Warsaw University, located in downtown Warsaw, and the meteorological station Okecie, located in the peripheries of the town. 


\section{WINTER (DECEMBER — FEBRUARY)}

The daily diagrams of air temperature in the winter months imply that during the whole day it is warmer in town than in its peripheries. The minimum of air temperature occurs outside of town usually at about 7:00 a.m., and it is delayed in downtown areas by 1,2 and even 4 hours. The daily

T O ${ }^{\circ} \mathrm{C} 20 / 21$ FEBRUARY' 64

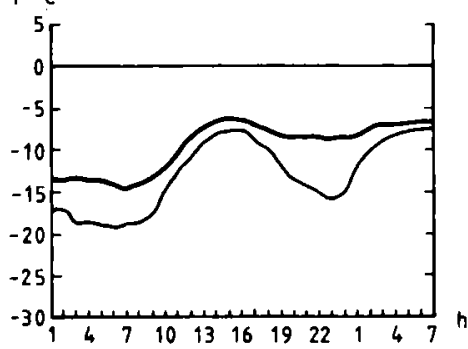

Fig. 1

Figs. 1, 2, 3 and 4. Diagrams of the course of air temperature at the University (downtown) and Okecie (periphery) stations during the selected typical days of-winter, spring, summer and autumn

- UW - Okęcie

maximum of air temperature occurs as a rule at the same time (at around 3:00 p.m.), or somewhat earlier in Okęcie, because the evening temperature decrease takes place earlier outside of town.

The morning rate of temperature increase $(\Delta T / \Delta t>0)$ is lower in town and it ranges from 0.2 to $1.0^{\circ} \mathrm{C} / \mathrm{h}$, sometimes a bit more: 1.4 to $1.8^{\circ} \mathrm{C} / \mathrm{h}$ and it attains its maximum usually $2-4$ hours after the minimum temperature has occurred. Outside of town the rate of heating is higher, as a rule exceeding $1^{\circ} \mathrm{C} / \mathrm{h}$, most frequently $1.5-2.5^{\circ} \mathrm{C} / \mathrm{h}$, and sometimes even above $3^{\circ} \mathrm{C} / \mathrm{h}$.

The temperature decrease rates in the evening and during the night $(\Delta T / \Delta t<0)$ are more differentiated: within the overbuilt areas the rates are slower and range from 0.1 to $0.7^{\circ} \mathrm{C} / \mathrm{h}$, while in the peripheries these rates are higher - above 1 and up to $3^{\circ} \mathrm{C} / \mathrm{h}$. Especially high (absolute) values of these rates occur between 5:00 and 9:00 p.m. Equalization of the rate value in the two kinds of points considered is observed between 7:00 and 9:00 a.m., see Figure 1.

\section{SPRING (MARCH - MAY)}

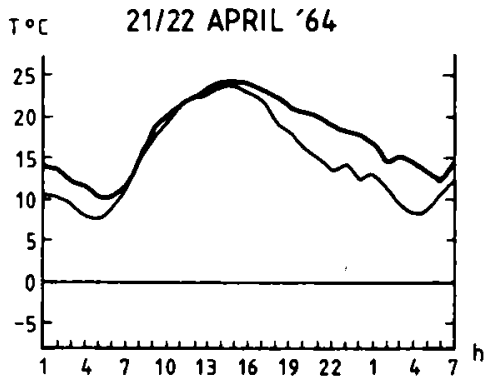

Fig. 2

In March and April it is still warmer in town than - or at least as warm as - in the peripheries, but in May it is already more often colder in town than outside of it. The daily minimum temperature is observed in the outskirts of town at 4:00-5:00 a.m., and some 1-2 hours later in the central parts of it. Equalization of temperature is observed, as before, between 7:00 and 9:00 a.m., more often near to 9:00. Daily maximum is usually observed in both points at 2:00-3:00 p.m. 
The rate of heating of the air before noon can vary considerably. The greatest temperature increases occur in the peripheral station Okęcie between 5:00 and 9:00 a.m., while in the downtown station (University) - between 8:00 and 10:00 a.m. In urban areas air heats up during the day more slowly than in its surroundings, with the respective rates ranging from 0.5 to $2.0^{\circ} \mathrm{C} / \mathrm{h}$. In the peripheries this rate ranges from approximately 1 to $3^{\circ} \mathrm{C} / \mathrm{h}$, but higher rate values were also observed.

The evening cooling starts between 3:00 and 5:00 p.m. and it amounts in the centre of town to up to $1^{\circ} \mathrm{C} / \mathrm{h}$, and in the surrounding areas - between 1 and $2^{\circ} \mathrm{C} / \mathrm{h}$. Before midnight the (absolute) values of these rates happen to be even higher $\left(1-1.5^{\circ} \mathrm{C} / \mathrm{h}\right.$ and $2-3^{\circ} \mathrm{C} / \mathrm{h}$, respectively), see Figure 2. During some days, when the intensity of the urban heat island is exceptionally high ( $\Delta T$ up to $6.3^{\circ} \mathrm{C}$ on April 22nd, 1964) the rate of cooling is yet bigger, reaching even $5^{\circ} \mathrm{C} / \mathrm{h}$.

\section{SUMMER (JUNE - AUGUST)}

During summer daily temperatures in town are as a rule lower than in the surrounding areas. The daily minimum of air temperature occurs in the peripheries at about 4:00- 5:00 a.m., and in town some one hour later. The increments of air temperature in town are the biggest between 7:00 and 10:00 a.m. (up to $2.8^{\circ} \mathrm{C} / \mathrm{h}$ ), while in the peripheries - earlier, namely between 5:00 and 9:00 a.m. $\left(3-4^{\circ} \mathrm{C} / \mathrm{h}\right)$. The average rate of temperature increase during the days with high intensity of the urban heat island is lower in the down-town overbuilt areas (approximately $1^{\circ} \mathrm{C} / \mathrm{h}$ ) than in the surrounding areas $\left(1-3^{\circ} \mathrm{C} / \mathrm{h}\right)$.

Similarly, the rate of cooling of the air is lower in the overbuilt downtown Warsaw than in the peripheries. This first rate

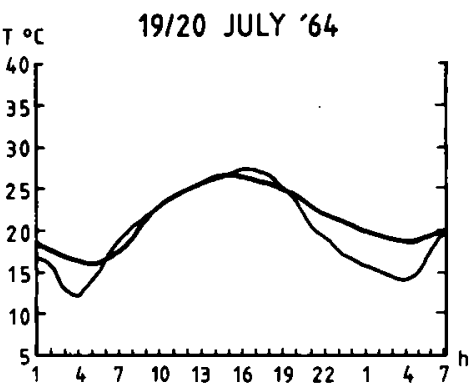

Fig. 3 is as a rule lower than $1^{\circ} \mathrm{C} / \mathrm{h}$, though between 8:00 and 12:00 p.m. it can be higher, between 1 and $2^{\circ} \mathrm{C} / \mathrm{h}$, but never exceeding $2.2^{\circ} \mathrm{C} / \mathrm{h}$. In the open space outside of town air cools down quicker, always at the rate higher than $1^{\circ} \mathrm{C} / \mathrm{h}$, in the extreme cases even up to $4.7^{\circ} \mathrm{C} / \mathrm{h}$ (see Fig. 3).

\section{AUTUMN (SEPTEMBER - NOVEMBER)}

During autumn the daytime temperatures in town are as a rule lower than in the peripheries. During the nighttime, on the other hand, between 


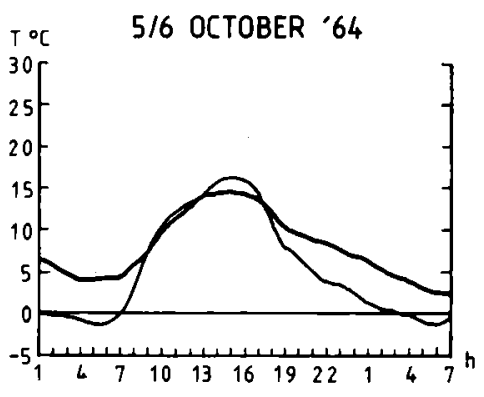

Fig. 4

9:00 p.m. and 4:00 a.m., the greatest thermal contrasts between the town and its environment are observed. The minimum of air temperature outside of town occurs at approximately 6:00 a.m. while in town it takes place 1 hour later or more or less at the same time.

The rate of warming up of the air in downtown Warsaw is on the average between 1 and $2^{\circ} \mathrm{C} / \mathrm{h}$, with the highest values observed between 8:00 and 11:00 a.m. In the open space outside of town this rate ranges from 1 to $3^{\circ} \mathrm{C} / \mathrm{h}$, with the higher values observed in the period 7:00-9:00 a.m. (even up to $4^{\circ} \mathrm{C} / \mathrm{h}$ ). The highest rates of warming up which were observed in the University station were $4.3-4.8^{\circ} \mathrm{C} / \mathrm{h}$ in the period 9:00-11:00 a.m., and in the Okęcie station $-6.1^{\circ} \mathrm{C} / \mathrm{h}$ in the period 7:00-9:00 a.m., on October 6th, 1964 .

The rate of cooling is lower in town, most often up to $2^{\circ} \mathrm{C} / \mathrm{h}$, and in the first hours of temperature decrease even only $1^{\circ} \mathrm{C} / \mathrm{h}$. Outside of town these rates vary between 2 and $3^{\circ} \mathrm{C} / \mathrm{h}$, attaining in the extreme cases $4^{\circ} \mathrm{C} / \mathrm{h}$ (see Fig. 4).

\section{CONCLUSIONS}

The heat island in Warsaw features characteristic annual profile, with higher intensity in the warmer and lower intensity in the cooler part of the year. The differences of temperature between the downton areas and the peripheries reach $1^{\circ} \mathrm{C}$ in terms of daily averages and $2^{\circ} \mathrm{C}$ in terms of minimum averages. The thermal influence of the urban buildings is especially strongly felt in summer and early fall, while it is the least significant in November and March. The contrast persists in winter round the clock, and in summer it intensifies in the evening and during the night. In individual cases, during the nighttime the downtown areas may be warmer than the peripheries by as much as 8 to $10^{\circ} \mathrm{C}$ (Wawer, 1994).

It is beyond doubt that the effect of the urban heat island, and especially the daily profile of its intensity, are linked with the difference in the rates of warming and cooling of the air in the urban areas and outside of town.

During the days when the heat island is well pronounced the rate of warming up of the air in the peripheries of town is rather constant irrespective of the season of the year, and it ranges from 1 to $3^{\circ} \mathrm{C} / \mathrm{h}$. In town this rate is lower, frequently below $1^{\circ} \mathrm{C} / \mathrm{h}$ (higher values appear in spring and in autumn, they do not exceed, though, $2^{\circ} \mathrm{C} / \mathrm{h}$ ).

The rate of cooling of the air in the peripheries is higher (in absolute terms) in autumn and in winter (even up to $3^{\circ} \mathrm{C} / \mathrm{h}$ ) than in spring and in summer $\left(1-2^{\circ} \mathrm{C} / \mathrm{h}\right)$. In town this rate is rather uniform and low (until mid- 
night up to $1^{\circ} \mathrm{C} / \mathrm{h}$ ), only in autumn the values up to $2^{\circ} \mathrm{C} / \mathrm{h}$ may occur. Still, changes in the rates depend upon the current weather conditions. When during the daytime the weather is sunny, cloudless or with little cloud cover, windless or with little wind, then the differences in the rates of cooling down of the air tend to be bigger (especially after midnight) and the heat island tends to be better pronounced. In the days when the heat island is less distinct, the rates of heating and cooling clearly decrease (on the average approximately $0.1-0.3^{\circ} \mathrm{C} / \mathrm{h}$ ).

\section{REFERENCES}

Kossowska U., 1973, Osobliwości klimatu wielkomiejskiego na przykładzie Warszawy (Peculiarities of the urban climate on the example of Warsaw). Prace i Studia IGUW, series Klimatologia, vol. 7.

St opa-Boryczka M., Kopacz-Lembowicz M., Kossowska-Cezak U., Ryczywolska E., Wawer J., 1984, Badania wplywu zabudowy na klimat lokalny $w$ Warszawie (Studies of the influence exerted by the overbuilt areas on the local climate in Warsaw), in: Proceedings of the I Polish Conference on "Climate and Bio-Climate of Towns", Lódź.

Stopa-Boryczka M., 1986, Deformation of fields of meteorological elements under the influence of buildings, Miscellanea Geographica, Warszawa.

Stopa-Boryczka M., Kopacz-Lembowicz M., Mierzwiński B., Wawer J., 1991, Zależność pola tem peratury powietrza od charakteru zabudowy (Dependence of the air temperature field on the nature of buildings). Acta Universitatis Wratislaviensis, no. 1213, Wrocław.

W a wer J., 1992, Zależność różnic temperatury powietrza między miastem a otoczeniem od pory dnia (Dependence of the differences of air temperature in town and outside of it upon the time of the day). Prace i Studia Geograficzne, vol. 11, Warszawa.

W a w e r J., 1994, Cechy termiczne klimatu lokalnego Warszawy (Thermal features of the local climate of Warsaw). Typescript in the Faculty of Geography and Regional Studies of the University of Warsaw. 
